ISSN (Online) 2722-1083,

VOL 3 No 1 OKTOBER 2021

\title{
PEMBERDAYAAN REMAJA DALAM UPAYA PENCEGAHAN DAN PENANGANAN ANEMIA PADA SISWA DI SMA SWASTA PERGURUAN PANCA BUDI MEDAN TAHUN 2019
}

\author{
Sri Widia Ningsih, Nadroh br Sitepu, Nurul Hidayah \\ ${ }^{a}$ Jurusan Teknologi Laboratorium Medis Poltekkes Medan \\ ${ }^{b}$ Jurusan Farmasi Poltekkes Medan \\ *Email: widianingsih29@gmail.com
}

\begin{abstract}
ABSTRAK. Pengabdian kepada masyarakat Poltekkes Kemenkes Medan dilakukan untuk mengingatkan masyarakat agar menjaga kesehatan melalui gerakan masyarakat hidup sehat telah dilakukan. Kegiatan Pengabdian Masyarakat berupa edukasi kepada remaja khususnya siswa/siswi SMA Swasta Perguruan Panca Budi Medan. Kegiatan Pengabdian ini akan difokuskan pada 2 subkegiatan, yaitu peningkatan pencegahan dan deteksi dini penyakit dengan cara pemeriksaan hemoglobin darah, peningkatan edukasi hidup sehat dengan simulasi mendapatkan, menggunakan, menyimpan dan membuang obat yang benar sebagai upaya promotif dan preventif khususnya untuk individu, keluarga dan masyarakat. Materi diberikan dengan konsep Health Edutainment (edukasi kesehatan yang menghibur) dengan terlebih dahulu melakukan penggalian seberapa dalam pengetahuan siswa terkait pendeteksian dini anemia pada remaja dan Dagusibu obat yang benar dengan pengisian kuesioner. Hasil penilaian kuesioner menunjukkan ingkat pemahaman responden pre materi anemia 2 orang kurang paham, 21 orang cukup paham dan 37 orang paham. Namun post materi anemia 57 orang responden paham dan 3 orang cukup paham. Tingkat pemahaman responden pre materi Dagusibu 19 orang kurang paham, 34 orang cukup paham dan 7 orang paham. Sedangkan post materi Dagusibu 32 orang responden cukup paham dan 28 orang paham. Hasil pemeriksaan 30 responden perempuan, 15 orang berisiko anemia, 16 orang normal. Sedangkan 26 responden laki-laki memiliki nilai haemoglobin darah normal, 3 orang berisiko anemia.
\end{abstract}

Kata Kunci: Anemia, Edukasi kesehatan, dagusibu, remaja

ABSTRACT. Community Services of the Medan Health Polytechnic is conducted to remind the public to maintain health through the movement of healthy living communities. Community services activities in the form of education to adolescents, especially students of Panca Budi College Private High School Medan. This service activity will be focused on 2 sub-activities, namely increasing prevention and early detection of diseases by examining hemoglobin, increasing education on healthy living with a simulation of correct obtaining, using, storing and disposing of drugs as promotive and preventive efforts especially for individuals, families and communities. The material will be given by the concept of Health Edutainment (entertaining health education) by first exploring how deeply the students' knowledge is related to early detection of anemia in adolescents and correct Dagusibu by filling out the questionnaire. The results of the questionnaire assessment showed that the level of understanding of respondents pre anemia lecture were 2 people did not understand, 21 people understood enough and 37 people understood. However, post anemia lecture showed that 57 respondents understood and 3 people understood enough. The level of understanding of respondent pre lecturer of Dagusibu were 19 people did not understand, 34 people understood enough and 7 people understood. While the post lecture of Dagusibu 32 respondents understood enough and 28 people understood. The results of the Haemoglobin measurement of 30 female respondents, 15 people 
ISSN (Online) 2722-1083, VOL 3 NO 1 OKTOBER 2021

at risk of anemia, 16 were normal. While 26 male respondents had normal blood hemoglobin values, 3 people were at risk of anemia.

Key Words: Anaemia, health education, teenager

\section{A. Pendahuluan}

Saat ini Indonesia tengah menghadapi tantangan besar yakni masalah kesehatan triple burden, karena masih adanya penyakit infeksi dan meningkatnya penyakit tidak menular (PTM). Meningkatnya PTM dapat menurunkan produktivitas sumber daya manusia, bahkan kualitas generasi bangsa. Penduduk usia produktif dengan jumlah besar yang seharusnya memberikan kontribusi pada pembangunan, justru akan terancam apabila kesehatannya terganggu oleh PTM dan perilaku yang tidak sehat.

Perubahan pola hidup masyarakat yang makin modern menjadi salah satu dasar GERMAS atau Gerakan Masyarakat Hidup Sehat dicanangkan oleh Kementrian Kesehatan Republik Indonesia. GERMAS adalah sebuah gerakan yang bertujuan untuk memasyarakatkan budaya hidup sehat serta meninggalkan kebiasaan dan perilaku masyarakat yang kurang sehat. Aksi GERMAS ini juga diikuti dengan memasyarakatkan perilaku hidup bersih sehat dan dukungan untuk program infrastruktur dengan basis masyarakat. GERMAS memiliki enam kegiatan utama, yaitu peningkatan aktivitas fisik, peningkatan perilaku hidup sehat, penyediaan pangan sehat dan percepatan perbaikan gizi, peningkatan pencegahan dan deteksi dini penyakit; peningkatan kualitas lingkungan, dan peningkatan edukasi hidup sehat.

Anemia merupakan masalah gizi yang banyak terdapat di seluruh dunia yang tidak hanya terjadi di negara berkembang tetapi juga di negara maju. Penderita anemia diperkirakan dua milyar dengan prevalensi terbanyak di wilayah Asia dan Afrika. World Health Organization (WHO) menyebutkan bahwa anemia merupakan 10 masalah kesehatan terbesar di abad modern ini, dimana kelompok yang berisiko tinggi anemia adalah wanita usia subur, ibu hamil, anak usia sekolah, dan remaja. Menurut WHO, apabila prevalensi anemia $\geq 40 \%$ termasuk kategori berat, sedang 20-39\%, ringan 5-19,9\%, dan normal $<5 \%$.

Anemia adalah keadaan dengan kadar hemoglobin, hematokrit dan sel darah merah yang lebih rendah dari nilai normal, yaitu hemoglobin $<12 \mathrm{~g} / \mathrm{dL}$ untuk remaja. Anemia menyebabkan darah tidak cukup mengikat dan mengangkut oksigen dari paru-paru ke seluruh tubuh. Bila oksigen yang diperlukan tidak cukup, maka akan berakibat pada sulitnya berkonsentrasi sehingga prestasi belajar menurun. Kemudian daya tahan fisik rendah sehingga mudah lelah, aktivitas fisik menurun dan mudah sakit karena daya tahan tubuh rendah, akibatnya jarang masuk sekolah atau bekerja.

Menurut data WHO dalam Worldwide Prevalence of Anemia menunjukkan bahwa total keseluruhan penduduk dunia yang menderita anemia sebanyak 1,62 miliar orang. Anemia pada remaja merupakan masalah kesehatan gizi di indonesia, karena menurut Riskesdas tahun 2013 menunjukkan 22,7\% remaja putri di Indonesia mengalami anemia gizi besi, begitupula menurut (World Health Organization) WHO prevalensi anemia remaja masih di atas $20 \%$. Anemia pada 
ISSN (Online) 2722-1083,

VOL 3 No 1 OKTOBER 2021

remaja berakibat menurunkan kemampuan dan konsentrasi belajar, mengganggu pertumbuhan sehingga tinggi badan tidak mencapai optimal, menurunkan kemampuan fisik olahragawati serta mengakibatkan muka pucat. Salah satu upaya yang dilakukan untuk menurunkan prevalensi anemia adalah dengan pemberian tablet tambah darah (TTD). Cakupan pemberian TTD pada remaja puteri (!2-18 tahun) di Sumatera Utara berdasarkan Data dan Informasi Profil Kesehatan Indonesia 2017, sebanyak 3,34\%.

Poltekkes Kemenkes Medan melakukan edukasi kepada remaja khususnya siswa/i SMA Swasta Perguruan Panca Budi Medan. Kegiatan Pengabdian ini akan difokuskan pada 2 sub-kegiatan, yaitu peningkatan pencegahan dan deteksi dini penyakit dengan cara pemeriksaan hemoglobin darah, peningkatan edukasi hidup sehat dengan simulasi mendapatkan, menggunakan, menyimpan dan membuang (Dagusibu) obat yang benar sebagai upaya promotif dan preventif khususnya untuk individu, keluarga dan masyarakat. Materi yang akan diberikan adalah konsep Health Edutainment (edukasi kesehatan yang menghibur) dengan terlebih dahulu melakukan penggalian seberapa dalam pengetahuan remaja terkait pendeteksian dini anemia pada remaja dan Dagusibu obat yang benar dengan pemberian kuesioner.

\section{B. Metode}

\section{Kerangka Pemecahan Masalah}

Masalah yang ada pada siswa/i SMA Swasta Perguruan Panca Budi Medan yaitu: a. Kurangnya pengetahuan mengenai deteksi dini penyakit anemia

b. Kurangnya pengetahuan tentang Dagusibu obat anemia oleh karena itu dilakukan pengabdian masyarakat dengan metode:

a. Melakukan penyuluhan mengenai deteksi dini penyakit anemia

b. Melakukan penyuluhan mengenai Dagusibu khususnya obat anemia

\section{Realisasi Pemecahan Masalah}

Pengabdian kepada masyarakat telah dilaksanakan pada hari Jumat, 02 Agustus 2019 di SMA Swasta Perguruan Panca Budi Medan, Jl. Jendral Gatot Subroto KM. 4,5 Sei Sikambing Medan.

\section{Khalayak Sasaran}

Sasaran pada kegiatan Pengabdian Masyarakat ini adalah 50 siswa/i SMA Swasta Perguruan Panca Budi Medan Jl. Jendral Gatot Subroto KM. 4,5 Sei Sikambing Medan.

\section{Prosedur Pelaksanaan Pengabdian Masyarakat}

1. Perencanaan kegiatan yang akan dilakukan. Proses perencanaan meliputi identifikasi kebutuhan, identifikasi potensi dan kelemahan yang ada, menentukan jalan keluar dan kegiatan yang akan dilakukan, dan membuat pengorganisasian kegiatan. Perencanaan dan pelaksanaan disusun oleh tim Pengabdian Masyarakat Jurusan Farmasi Poltekkes Medan. Sedangkan tim SMA Swasta Perguruan Panca Budi akan bertindak sebagai fasilitator.

2. Pelaksanaan kegiatan. Kegiatan dilaksanakan bersamasama dengan 
ISSN (Online) 2722-1083,

VOL 3 No 1 OKTOBER 2021

mahasiswa dengan perencanaan tahapan: pemberian kuesioner untuk melihat kedalaman pengetahuan siswa/i SMA Swasta Perguruan Panca Budi mendeteksi dini penyakit anemia pada remaja dan Dagusibu obat yang benar. Selanjutnya melakukan pemeriksaan haemoglobin dan simulasi pengetahuan remaja terkait Dagusibu obat khususnya obat anemia yang benar sebagai upaya peningkatan edukasi hidup sehat.

3. Monitoring dan evaluasi kegiatan berupa pemberian kuesioner pasca edukasi dan simulasi. Proses ini juga dilakukan oleh tim Pengabdian Masyarakat Jurusan Farmasi Poltekkes Medan kepada siswa/i SMA Swasta Perguruan Panca Budi. Tim pengabdian dan Tim SMA Swasta Perguruan Panca Budi juga akan bertindak sebagai fasilitator.

\section{Keterkaitan}

Diharapkan mampu menambah pengetahuan dan pemahaman siswa/i SMA Swasta Perguruan Panca Budi Medan terhadap GERMAS dalam mendeteksi dini penyakit dengan melakukan pemeriksaan hemoglobin darah dan bagaimana pengetahuan remaja terkait Dagusibu obat yang benar sebagai upaya peningkatan edukasi hidup sehat.

Sedangkan keterkaitan terhadap institusi Jurusan farmasi diharapkan dapat dijadikan sarana informasi dan promosi pelayanan pendidikan sekaligus memperkenalkan Poltekkes Kemenkes Medan kepada siswa/i SMA Swasta Perguruan Panca Budi Medan yang akan melanjutkan pendidikannya kejenjang perguruan tinggi.

\section{Waktu dan Tempat Kegiatan}

Hari/Tanggal : Jumat/2 Agustus 2019

Pukul

:09.00/selesai

Tempat

: SMA Swasta Perguruan

Panca Budi Medan Jl.

Jendral Gatot

Subroto KM. 4,5 Sei

Sikambing Medan

\section{Sarana dan Alat yang Digunakan}

Kuesioner pra dan post materi Anemia dan Dagusibu, Aula SMA Swasta Perguruan Panca Budi Medan, OHP, Seperangkat Audio, Laptop, Easy touch $H b$, Stick Easy touch $H b$, Sendok takar, Gelas Ukur, Spanduk, paket Goodie Bag.

\section{Evaluasi}

Evaluasi dilaksanakan secara pre dan post untuk materi Anemia menggunakan 25 pertanyaan kuesioner dan materi Dagusibu menggunakan 10 pertanyaan kepada SMA Swasta Perguruan Panca Budi Medan yang telah didata. Kriteria dan indikator tercapainya tujuan dinilai dari diperolehnya skor kuesioner diatas (>) dari 50 yang menunjukkan tingkat kefahaman siwa/i setelah dilakukannya edukasi.

\section{Hasil dan Pembahasan}

Hasil

1. Tingkat Pemahaman Responden terhadap Deteksi Dini Penyakit Anemia Untuk menilai tingkat pemahaman responden terhadap deteksi dini penyakit anemia dilakukan penilaian dengan pengisian kuesioner sebelum (pre) dan setelah (post) diberikan intervensi berupa edukasi Penyakit Anemia kepada 60 
ISSN (Online) 2722-1083,

VOL 3 No 1 OKTOBER 2021

siswa/i SMA Swasta Perguruan Panca Budi Medan yang terdiri dari 33 siswa dan 27 siswi. Perhitungan skor kuesioner pengetahuan anemia dihitung berdasarkan banyaknya jumlah skor jawaban benar dibagi skor total kuesioner dikalikan dengan 100 persen (\%) (Lampiran 11) Hasil kuesioner tersebut dapat dilihat dari grafik di bawah ini.

skor jawaban benar dibagi skor total kuesioner dikalikan dengan 100 persen (\%) (Lampiran 11). Hasil kuesioner tersebut dapat dilihat dari grafik di bawah ini.

\section{Gambar 2. Grafik Gambaran Tingkat Pemahaman Responden terhadap Dagusibu Obat}

\section{Pemeriksaan Kadar Haemoglobin}

Gambaran Tingkat Pemahaman Responden Pre \& Post Materi Anemia

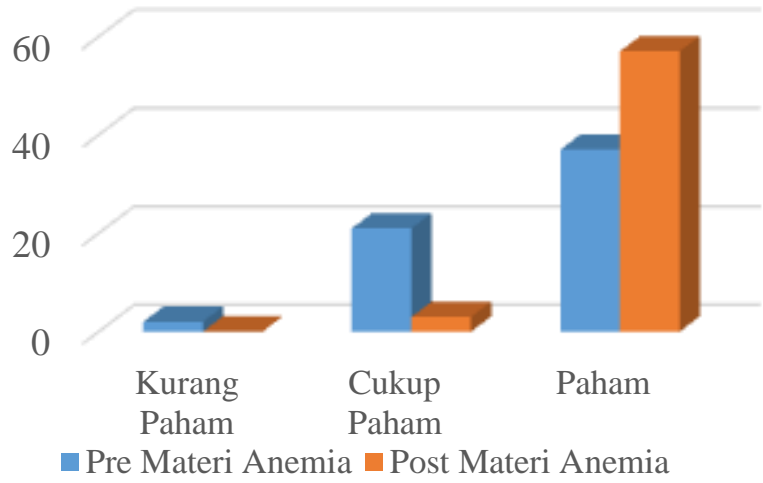

Gambar 1. Grafik Gambaran Tingkat Pemahaman Responden terhadap Deteksi Dini Penyakit Anemia

\section{Tingkat Pemahaman Responden terhadap Dagusibu Obat}

Untuk menilai tingkat pemahaman responden terhadap Dagusibu obat khususnya anemia dilakukan penilaian dengan pengisian kuesioner pre dan post diberikan intervensi berupa edukasi Dagusibu 60 siswa/i SMA Swasta Perguruan Panca Budi Medan. Perhitungan skor kuesioner pengetahuan Dagusibu dihitung berdasarkan banyaknya jumlah
Gambaran Tingkat Pemahaman Responden Pre \& Post Materi Dagusibu

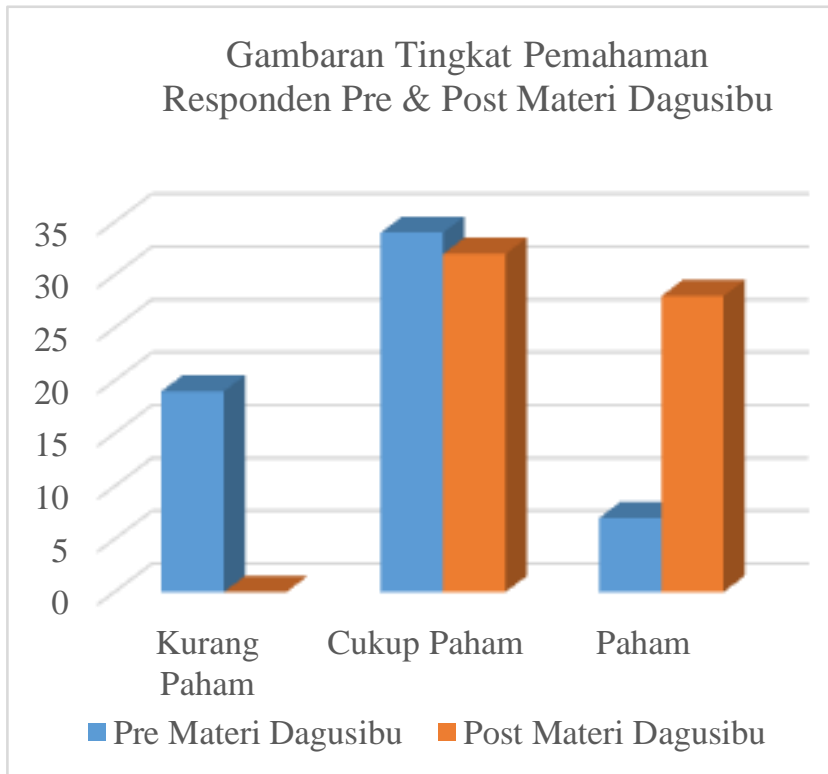

\section{Responden}

Pemeriksaan kadar haemoglobin dilakukan terhadap 60 siswa/i SMA Swasta Perguruan Panca Budi Medan. Pengkategorian kadar haemoglobin respoden dibuat berdasarkan nilai yang ditentukan oleh Kementerian Kesehatan pada nilai haemoglobin laki-laki dan wanita dewasa (Lampiran 11). Hasil pemeriksaan dapat dilihat dari grafik di bawah ini. 
ISSN (Online) 2722-1083,

VOL 3 No 1 OKTOBER 2021

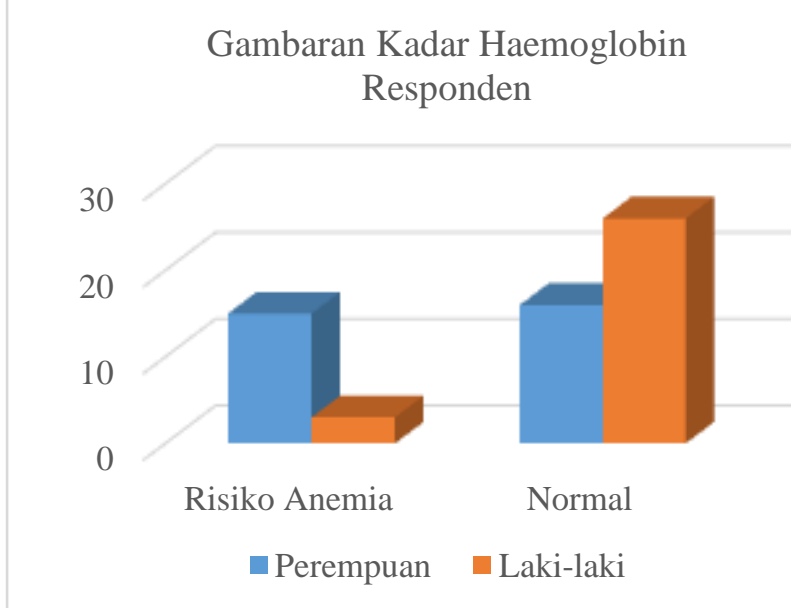

Gambar 3. Grafik Gambaran Kadar Haemoglobin Responden

\section{Pembahasan}

\section{Tingkat Pemahaman Responden terhadap Deteksi Dini Penyakit Anemia}

Tingkat pemahaman responden terhadap Deteksi Dini Penyakit Anemia diukur dari hasil kuesioner yang diberikan kepada responden pre dan post. Pemberian skor dibagi atas kurang paham (<50), cukup paham (50-75), paham (>75). Berdasarkan grafik 4.1 diketahui bahwa tingkat pemahaman responden pre materi anemia 2 orang kurang paham, 17 orang cukup paham dan 37 orang paham. Namun post materi anemia menunjukkan peningkatan signifikan menjadi 57 orang responden paham dan 3 orang cukup paham.

\section{Tingkat Pemahaman Responden terhadap Dagusibu Obat}

Tingkat pemahaman responden terhadap Dagusibu diukur dari hasil kuesioner yang diberikan kepada responden pre dan post. Pemberian skor dibagi atas kurang paham $(<50)$, cukup paham (50-75), paham (>75). Berdasarkan grafik 4.2 diketahui bahwa tingkat pemahaman responden pre materi Dagusibu 19 orang kurang paham, 34 orang cukup paham dan 7 orang paham. Sedangkan post materi Dagusibu menunjukkan peningkatan signifikan menjadi 32 orang responden cukup paham dan 28 orang paham.

Selanjutnya setelah diberikan kedua materi baik anemia dan Dagusibu,diajukan pertanyaan yang berkaitan dengan materi kepada responden secara lisan, antusias responden dalam menjawab pertanyaanpertanyaan yang dilontarkan cukup tinggi dan isi jawaban cukup baik. Dari responden yang mampu menjawab pertanyaan dengan tepat, diberikan door prize menarik.

\section{Pemeriksaan Kadar Haemoglobin Responden}

Pemeriksaan kadar haemoglobin darah responden dilakukan dengan menggunakan alat easy touch. Nilai Dari Haemoglobin darah remaja dianggap normal jika $>12$ $\mathrm{mg} / \mathrm{dL}$. Dari hasil pemeriksaan 30 responden perempuan, 15 orang berisiko anemia, 16 orang normal. Sedangkan 26 responden laki-laki memiliki nilai haemoglobin darah normal, 3 orang berisiko anemia.

\section{Simpulan}

Dari hasil pengabdian masyarakat yang dilakukan dapat disimpulkan bahwa:

a. Tingkat pemahaman responden pre materi anemia 2 orang kurang paham, 21 orang cukup paham dan 37 orang paham. Namun post materi anemia 57 orang responden paham dan 3 orang cukup paham. 
ISSN (Online) 2722-1083,

VOL 3 No 1 OKTOBER 2021

b. Tingkat pemahaman responden pre materi Dagusibu 19 orang kurang paham, 34 orang cukup paham dan 7 orang paham. Sedangkan post materi Dagusibu 32 orang responden cukup paham dan 28 orang paham.

c. Dari hasil pemeriksaan 30 responden perempuan, 15 orang berisiko anemia, 16 orang normal. Sedangkan 26 responden laki-laki memiliki nilai haemoglobin darah normal, 3 orang berisiko anemia.

\section{Terimaka Kasih}

Terimakasih kepada Poltekkes Kemenkes Medan yang telah memberikan dukungan dana BOPTN (Bantuan Operasional Perguruan Tinggi Negeri) dan telaah laporan hasil pengabdian masyarakat.

\section{Daftar Pustaka}

Dinas Kesehatan Provinsi Sumatera Utara. 2012. Profil Kesehatan Provinsi Sumatera Utara tahun 2012.

Kementerian Kesehatan RI. 2016. Buku Panduan Germas. Jakarta

Kementerian Kesehatan RI. 2016. Gerakan Masyarakat Hidup Sehat (GERMAS). (Online), (Http://www.depkes.go.id)

Kementerian Kesehatan RI. 2016. Permenkes No 39 Tahun 2016 Tentang Pedoman Penyelenggaraan Program Indonesia Sehat dengan Pendekatan Keluarga. (Online), (Http://www.depkes.go.id)

Lopez AD, Mathers CD, Ezzati M, Jamison DT, Murray CJL. 2006. Global and regional burden of disease and risk factors, 2001: systematic analysis of population health data. The Lancet 367: 174757.

Moh. Nasir, Ph.D, 1999, Metode Penelitian, Ghalia Indonesia.

Noviyani A, Yuliani D.A. 2017. Upaya Penanggulangan Anemia Gizi Remaja Putri di MTS Muhammadiyah Purwokerto Kabupaten Banyumas. Seminar Nasional Hasil Penelitian dan Pengabdian Masyarakat III Tahun 2017. Pengembangan Sumberdaya Menuju Masyarakat Madani Berkearifan Lokal. Purwokerto, 19 Desember 2019. ISBN: 978-6026697-20-2

Rokhmawati,IA. 2015. Efek Penyuluhan Gizi dengan Media Leaflet terhadap Tingkat Pengetahuan tentang Anemia pada Remaja Putri di SMP Kristen 1 Surakarta. Skripsi. Universitas Muhammadiyah Surakarta.

Setyoadi, Ahsan dan Abidin, A.A. 2013. Hubungan peran kader kesehatan dengan tingkat kualitas hidup lanjut usia. Jurnal Ilmu Keperawatan, Vol : 1 , No. 2

Yati K, Dwitiyanti H, Lestari PM. 2018. Pelatihan Pengelolaan Obat yang Tepat dan Benar di UKS SekolahSekolah Muhammadiyah Wilayah DKI Jakarta. Jurnal Solma. Vol. 07, No.1 pp. 42-49.

Yatim, Faisal. 2003. Talasemia Leukimia dan Anemia. Jakarta:Yayasan Obor Indonesia anemia. 
JURNAL MITRA PRIMA (JMP) UNIVERISTAS PRIMA INDONESIA MEDAN

ISSN (Online) 2722-1083,

VOL 3 No 1 OKTOBER 2021 